\title{
Optimization with Response Surface Methodology of Microwave-Assisted Conversion of Xylose to Furfural
}

\author{
Carmen Padilla-Rascón ${ }^{1,2}$, Juan Miguel Romero-García ${ }^{1,2}{ }^{-0}$, Encarnación Ruiz ${ }^{1,2, *}$ and \\ Eulogio Castro ${ }^{1,2}$ (D)
}

1 Department of Chemical, Environmental and Materials Engineering, Universidad de Jaén, Campus Las Lagunillas, 23071 Jaén, Spain; cpadilla@ujaen.es (C.P.-R.); jrgarcia@ujaen.es (J.M.R.-G.); ecastro@ujaen.es (E.C.)

2 Centre for Advanced Studies in Earth Sciences, Energy and Environment (CEACTEMA), Universidad de Jaén, Campus Las Lagunillas, 23071 Jaén, Spain

* Correspondence: eruiz@ujaen.es; Tel.: +34-953212779

Academic Editors: Alejandro Rodríguez, Eduardo Espinosa and Sylvain Caillol Received: 9 June 2020; Accepted: 30 July 2020; Published: 6 August 2020

\begin{abstract}
The production of furfural from renewable sources, such as lignocellulosic biomass, has gained great interest within the concept of biorefineries. In lignocellulosic materials, xylose is the most abundant pentose, which forms the hemicellulosic part. One of the key steps in the production of furfural from biomass is the dehydration reaction of the pentoses. The objective of this work was to assess the conditions under which the concentration of furfural is maximized from a synthetic, monophasic, and homogeneous xylose medium. The experiments were carried out in a microwave reactor. $\mathrm{FeCl}_{3}$ in different proportions and sulfuric acid were used as catalysts. A two-level, three-factor experimental design was developed for this purpose. The results were further analyzed through a second experimental design and optimization was performed by response surface methodology. The best operational conditions for the highest furfural yield (57\%) turned out to be $210{ }^{\circ} \mathrm{C}, 0.5 \mathrm{~min}$, and $0.05 \mathrm{M} \mathrm{FeCl}_{3}$.
\end{abstract}

Keywords: lignocellulosic material; xylose; furfural; iron chloride; microwave reactor; biorefinery

\section{Introduction}

Owing to the depletion of fossil resources, it is necessary to look for renewable sources for the production of fuels and chemicals. Lignocellulosic biomass is an alternative natural resource that presents multiple advantages, because of its abundance, renewability, low cost, and the fact that it is a waste product with no competing uses. Lignocellulosic materials are mainly composed of hemicellulose, cellulose, and lignin. Other fractions also present in a lower proportion are extractives, which are low molecular weight organic compounds, and the ashes, which are inorganic compounds. Although the chemical composition of the biomass is variable, hemicellulose is usually the second most abundant compound with multiple uses, after cellulose. Xylose is the most abundant pentose in the hemicelluloses of hardwoods and agricultural plants [1].

In recent years, the production of furfural from renewable sources has gained great attention within the concept of sustainable biorefineries, giving added value to lignocellulosic materials and advancing the sustainable bioeconomy. The U.S. Department of Energy identified furfural as one of the top 30 platform chemicals [2]. Its composition, formed by unsaturated bonds and aldehyde groups, makes it a versatile platform molecule, from which a great variety of chemical compounds can be obtained, with applications in oil refining, production of plastics, food, and pharmaceutical and agricultural industries [3-5]. 
Currently, the most commonly used lignocellulosic biomasses for production of furfural are corn cob, sugar cane bagasse, rice hull, and wheat bran, considering that they are rich in hemicelluloses and are available in large quantities [1]. Olive subproducts, specifically olive stones or pits, have also been used to obtain furfural [6]. Among the advantages of using olive pits, the high availability in Mediterranean areas, their composition with a high proportion of hemicelluloses, and their easy acid hydrolysis are frequently cited.

Furfural is obtained from lignocellulosic materials in two steps, as shown briefly in Figure 1. The first step reaction, hydrolysis, consists of the transformation of polysaccharides into monosaccharides, obtaining a hydrolysate rich in sugars; in this case, the predominant sugar is xylose. The second step is the dehydration reaction of pentoses, mainly xylose, to furfural. This process can be done within the same reactor, one-stage, or separately in two steps. When the process is carried out in two steps, the hydrolysate can be separated from the insolubilized solid after the first step, allowing greater utilization of the lignocellulosic material. Furfural is obtained by dehydration of the pentoses (mainly xylose) and the unhydrolyzed solid can be employed for other uses, such as enzymatic hydrolysis and fermentation [7].

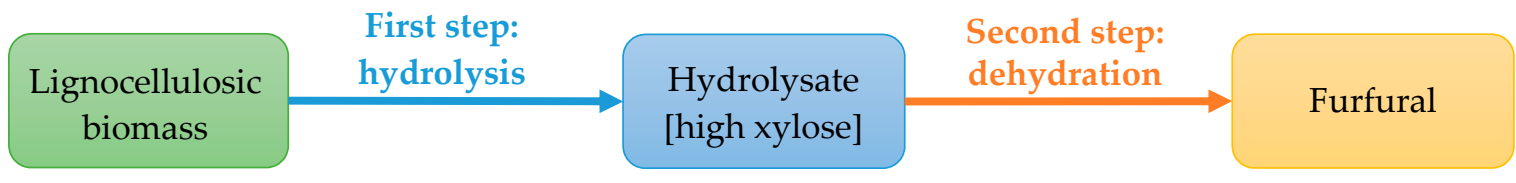

Figure 1. Schematic diagram of furfural production from lignocellulosic biomass.

The pentose dehydration reaction involves the protonation of three carbon atoms in the sugar ring, removing three water molecules and obtaining the furanic molecules. Normally, these reactions take place in an aqueous medium, owing to its polarity, availability, sustainability, and low price. In the dehydration reaction, undesired secondary reactions also occur, by condensation between the furfural and the intermediate products of dehydration and by the degradation of the pentoses to low molecular weight products, generating soluble and insoluble secondary products (called humins) [8]. The use of catalysts facilitates the dewatering reaction. Most of the catalysts studied have Brønsted sites, which directly dehydrate the initial carbohydrate. Furthermore, the use of Lewis acid sites favors the isomerization of the carbohydrate and the subsequent dehydration through the Brønsted sites. These catalysts can be homogeneous, the disadvantages of which are high pressure and the production of a corrosive acid stream that needs to be neutralized. Alternatively, heterogeneous catalysts, limited by their cost and synthesis, are also used and may be subjected to deactivation owing to the deposit of subproducts on their surface $[9,10]$.

Hemicellulose-rich raw materials can be hydrolyzed by various processes, among which the dilute acid hydrolysis stands out as one of the most efficient to selectively recover hemicellulose sugars $[7,11,12]$. These acids, like sulfuric acid, also enhance the dehydration reaction, in which it acts as Lewis acid [13]. Furthermore, the potential of salts as a catalyst for these reactions has been corroborated in multiple studies. Metal salts, and especially metal chlorides, such as $\mathrm{FeCl}_{3}$, have been used in the pretreatment step of lignocellulosic materials to improve the generation of sugars that can in turn be converted into valuable chemicals, acting also as a catalyst for the dehydration of sugars into furfural, as a prominent example. According to the proposed mechanism by which this general process takes place, $\mathrm{FeCl}_{3}$ acts as Brønsted acid in several reactions whose equilibrium is influenced by the $\mathrm{pH}$ and the initial concentration of the metal salt, improving the performance in obtaining furfural $[4,14,15]$. A complete description of the way metal salts can act for pretreating lignocellulosic materials along with relevant examples is available elsewhere [16].

Microwave-assisted reactions are booming, as they have many advantages, for example, they are versatile, need shorter reaction times, present uniform heating, and can be more efficient reactions. In multiple studies, microwave-assisted heating resulted in better yields compared with traditional heating methods $[10,17,18]$. Microwaves are widely used with lignocellulosic materials for the 
production of value-added chemicals such as furfural $[5,19]$. Another application is the fractionation of lignocellulosic materials. For example, Zhang et al. [20] reported on a microwave-assisted organoslv pretreatment using raw poplar. In another study, rye and wheat stillage were submitted to a first microwave treatment to produce a highly concentrated sugar solution, which was further fermented to ethanol [21]. Microwaves were also used to assist hemicellulose extraction from corn fiber [22], or for extracting phenolics from cocoa pod husk [23]. Recently, microwave-assisted treatment by deep eutectic solvents was reported for the delignification of garlic skin [24].

Response surface methodology is a tool that allows obtaining a mathematical model to establish a relationship between the parameters of interest studied (temperature, time, and so on) and the results obtained (yields, conversions, and so on). The interrelationships between the factors studied and their influence on the responses obtained are analyzed statistically to determine their significance. It also allows finding the best experimental conditions based on the results. The use of this methodology is widespread when optimizing the process conditions for furfural production [25-27].

As a previous step to get useful information on the best conditions to produce furfural from the pentose fraction of lignocellulosic materials, this paper addresses the use of sulfuric acid and ferric chloride to obtain furfural from a solution with a high concentration of xylose $(30 \mathrm{~g} / \mathrm{L})$ in a monophasic and homogeneous medium. The microwave heating technique is used because of its advantages. The main objective is to optimize the conditions for the highest furfural production. For this purpose, two experimental designs were made, with temperature, time, and concentration of ferric chloride as factors.

\section{Results}

\subsection{Two-Level Factorial Design}

The results obtained from the factorial design of 11 experiments $\left(2^{3}+3\right.$ central points $)$ with the three factors studied (concentration of $\mathrm{FeCl}_{3}$, time, and temperature) are shown in Table 1. The initial concentration of xylose was $30 \mathrm{~g} / \mathrm{L}$, while the consumption values ranged between 7.52 and $29.44 \mathrm{~g} / \mathrm{L}$, which is equivalent to conversion between 25.06 and $98.13 \%$ (above $90 \%$ in most cases). As for the furfural obtained, the values were between 3.02 and $10.35 \mathrm{~g} / \mathrm{L}$, which represents a yield of 15.63 and $53.59 \%$, respectively. Finally, the selectivity ranged between 25.83 and $62.38 \%$, with the average above $45 \%$.

Table 1. Two-level, three-factor experimental design. Experimental conditions and response results.

\begin{tabular}{ccccccccc}
\hline Run & \multicolumn{3}{c}{ Factors } & \multicolumn{5}{c}{ Responses } \\
\hline & $\begin{array}{c}\mathbf{A}: \mathrm{FeCl}_{\mathbf{3}} \\
\mathbf{( M )}\end{array}$ & $\begin{array}{c}\text { B: Time } \\
(\mathbf{m i n})\end{array}$ & $\begin{array}{c}\mathbf{C}: \text { Temp. } \\
\left({ }^{\circ} \mathbf{C}\right)\end{array}$ & $\begin{array}{c}\text { Xylose } \\
\text { Consumed (g/L) }\end{array}$ & $\begin{array}{c}\text { Furfural } \\
(\mathbf{g} / \mathbf{L})\end{array}$ & Yield(\%) & $\begin{array}{c}\text { Conversion } \\
\mathbf{( \% )}\end{array}$ & $\begin{array}{c}\text { Selectivity } \\
\mathbf{( \% )}\end{array}$ \\
\hline 2 & 0.3 & 1 & 170 & 16.68 & 4.79 & 24.87 & 55.61 & 44.73 \\
4 & 0.1 & 5 & 200 & 29.33 & 7.84 & 38.99 & 97.77 & 39.88 \\
6 & 0.1 & 5 & 170 & 18.11 & 6.52 & 33.87 & 60.38 & 56.10 \\
7 & 0.3 & 1 & 200 & 29.44 & 7.96 & 41.13 & 98.13 & 41.91 \\
8 & 0.3 & 5 & 170 & 26.75 & 7.72 & 39.93 & 89.15 & 44.79 \\
9 & 0.1 & 1 & 200 & 29.07 & 10.35 & 53.59 & 96.91 & 55.30 \\
10 & 0.1 & 1 & 170 & 7.52 & 3.02 & 15.63 & 25.06 & 62.38 \\
11 & 0.3 & 5 & 200 & 28.99 & 4.82 & 24.96 & 96.63 & 25.83 \\
1 & 0.2 & 3 & 185 & 29.04 & 8.91 & 45.61 & 96.80 & 47.12 \\
3 & 0.2 & 3 & 185 & 29.13 & 9.05 & 45.70 & 97.12 & 47.06 \\
5 & 0.2 & 3 & 185 & 28.55 & 9.16 & 45.71 & 95.18 & 48.02 \\
\hline
\end{tabular}

An overview of the results shows that increasing temperature also produced an increase in the xylose consumed and the furfural produced, indicating that the temperature favours the dehydration of xylose and the production of furfural, but it can also be seen that this does not only depend on the temperature factor. For determining the effect of the factors studied (concentration of $\mathrm{FeCl}_{3}$, time, and temperature) on yield (furfural yield), conversion (xylose conversion), and selectivity (furfural 
selectivity), the results were statistically analyzed and modelled according to a linear model with interaction between the factors. The models obtained in coded terms together with the $p$-value, $R^{2}$, coefficient of variation (CV), and standard deviation (SD) are shown in Table 2. As can be seen, for all models, the $R^{2}$ obtained is in the order of 0.99 ( $99 \%$ of the change is produced by the factors studied) and $\mathrm{CV}$ in all cases is lower than $3.2 \%$.

Table 2. Models in coded terms obtained for yield, conversion, and selectivity in a factorial design. $\mathrm{A}=$ concentration of $\mathrm{FeCl}_{3}, \mathrm{~B}=$ time, and $\mathrm{C}=$ temperature. $\mathrm{CV}$, coefficient of variation.

\begin{tabular}{|c|c|c|c|c|c|}
\hline Response & Model (Coded Terms) & $p$-Value & $R^{2}$ & CV (\%) & SD (\%) \\
\hline Yield (\%) & $\begin{array}{c}\text { Yield }=34.12-1.40 \cdot \mathrm{A}+0.32 \cdot \mathrm{B}+5.55 \cdot \mathrm{C}- \\
5.22 \cdot \mathrm{AC}-8.01 \cdot \mathrm{BC}\end{array}$ & $<0.0001$ & 0.997 & 2.38 & 0.89 \\
\hline Conversion (\%) & $\begin{array}{c}\text { Conversion }=77.45+7.43 \cdot \mathrm{A}+8.53 \cdot \mathrm{B}+ \\
19.91 \cdot \mathrm{C}-7.41 \cdot \mathrm{AC}-8.69 \cdot \mathrm{BC}\end{array}$ & $<0.0001$ & 0.999 & 1.26 & 1.04 \\
\hline Selectivity (\%) & $\begin{array}{c}\text { Selectivity }=46.36-7.05 \cdot \mathrm{A}-4.71 \cdot \mathrm{B}-5.63 \cdot \mathrm{C} \\
-3.16 \cdot \mathrm{BC}\end{array}$ & $<0.0001$ & 0.988 & 3.18 & 1.48 \\
\hline
\end{tabular}

The temperature $(\mathrm{C})$ is the most influential factor on the yield, as can be deduced from the highest value of its coefficient (contribution $>20 \%$ ); moreover, the total contribution of the temperature, if the interaction concentration $\mathrm{FeCl}_{3}$-temperature $(\mathrm{AC})$ and the interaction time-temperature $(\mathrm{BC})$ are taken into consideration, represents more than $75 \%$. At a low temperature, the yield increases with the concentration of $\mathrm{FeCl}_{3}(\mathrm{~A})$, while at a high temperature, the yield decreases with the increasing concentration of $\mathrm{FeCl}_{3}$. Similar yield results are obtained at high concentrations of $\mathrm{FeCl}_{3}$, independently of the temperature (Figure 2a). As far as the interaction between temperature and time is concerned, yields increase with time (B) in the low temperature region, while the behavior is the opposite at a high temperature (Figure $2 b$ ).

Regarding the conversion, a similar pattern to that in the yield was observed, that is, the temperature is the most influential factor. In this case, the contribution of the linear term is more than $52 \%$ and, together with $\mathrm{AC}$ and $\mathrm{BC}$ interactions, it represents $70 \%$. In the case of conversion, the other two factors have a greater influence, contributing $17 \%$. At a high temperature, the conversion is high regardless of the $\mathrm{FeCl}_{3}$ concentration and, at a low temperature, the conversion increases with the $\mathrm{FeCl}_{3}$ concentration, not reaching as high as at a high temperature (Figure 2c). The interaction between temperature and time follows the same trend described above for conversion (Figure 2d).

Finally, in the case of selectivity, the influence of the factors studied is different from the two previous cases, because the most influential factor is the $\mathrm{FeCl}_{3}$ concentration, with a contribution of more than $43 \%$, with that of temperature and time being $27 \%$ and $19 \%$, respectively. These last two factors interact in such a way that, at a low temperature, the selectivity decreases slightly over time and, at a high temperature, the selectivity decreases more drastically over time (Figure 2e).

When looking for the conditions that could maximize the variables studied only in the case of selectivity, we can say, without the need to make calculations, that they would be the lowest of all the factors studied $\left(\left[\mathrm{FeCl}_{3}\right]=0.1 \mathrm{M}\right.$, time $=1 \mathrm{~min}$, and temperature $\left.=170^{\circ} \mathrm{C}\right)$, because all the coefficients of the model obtained are negative (Table 2). In the case of yield and conversion, calculations would be necessary because, among the coefficients of their models, there are positive and negative values, but, if Figure 2 is observed, they can also be deduced. For the conversion, it can be easily deduced from Figure $2 \mathrm{c}, \mathrm{d}$ that the best conditions are the high temperature $\left(200^{\circ} \mathrm{C}\right)$ and, in that case, the concentration of $\mathrm{FeCl}_{3}$ and time has little influence, so one would opt for low values $\left(\left[\mathrm{FeCl}_{3}\right]=0.1 \mathrm{M}\right.$, time $\left.=1 \mathrm{~min}\right)$. In the case of the yield, observing Figure $2 \mathrm{a}, \mathrm{b}$, it is also easy to deduce that the best conditions would be $200{ }^{\circ} \mathrm{C},\left[\mathrm{FeCl}_{3}\right]=0.1 \mathrm{M}$, and $1 \mathrm{~min}$. 


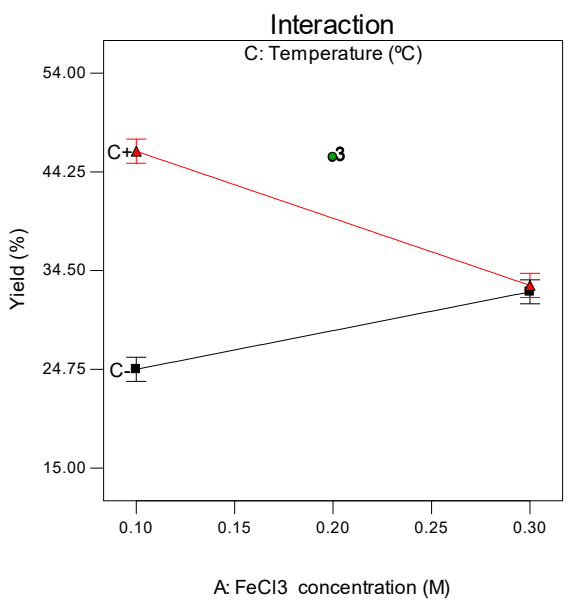

(a)

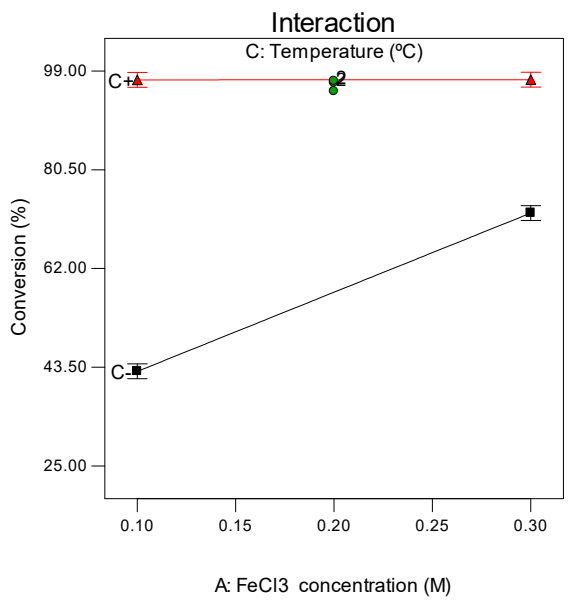

(c)

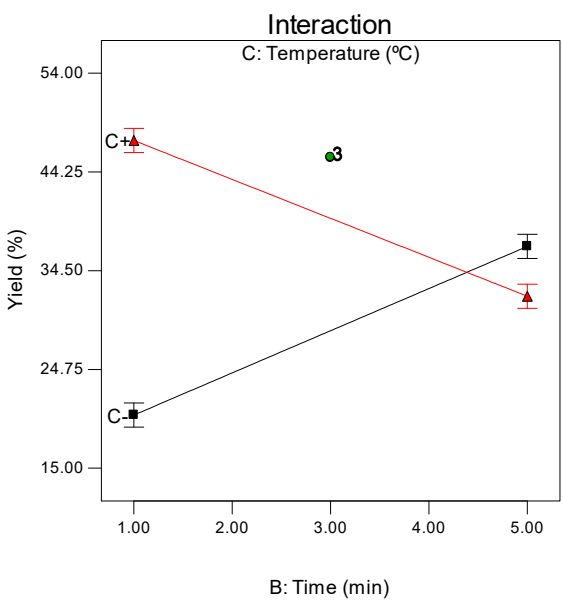

(b)

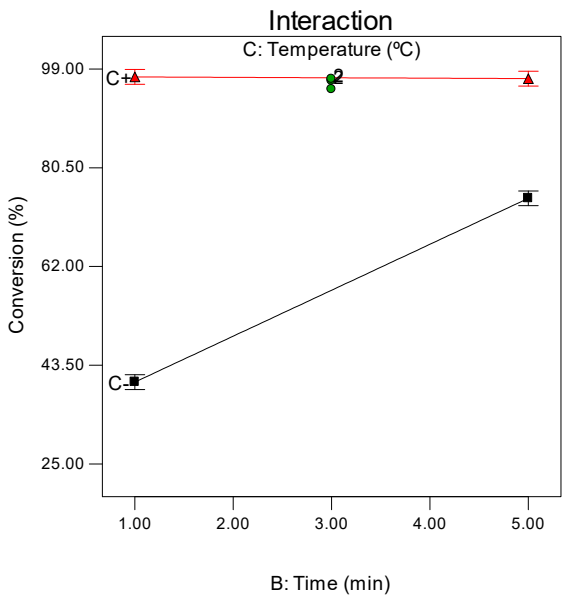

(d)

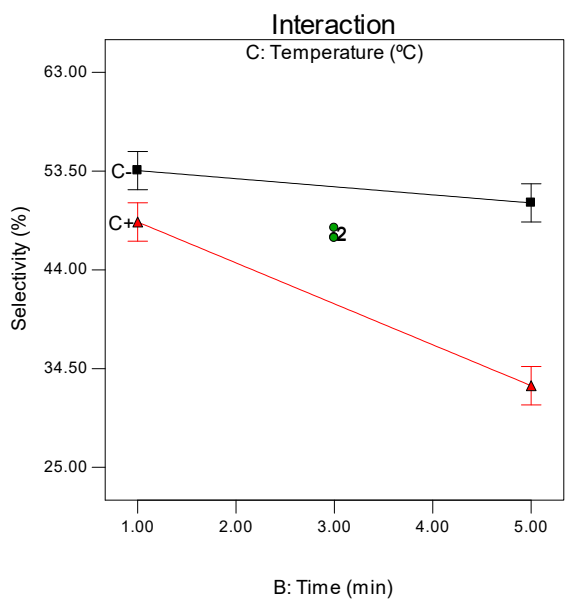

(e)

Figure 2. Interaction of factors studied in the factorial design: (a) interaction of $\mathrm{FeCl}_{3}$ concentration and temperature in yield; (b) interaction of time and temperature in yield; (c) interaction of $\mathrm{FeCl}_{3}$ concentration and temperature in conversion; (d) interaction of time and temperature in conversion; (e) interaction of time and temperature in selectivity. Red line, $200{ }^{\circ} \mathrm{C}$; black line, $170{ }^{\circ} \mathrm{C}$. 


\subsection{Central Composite Design}

On the basis of the results obtained in the two-level factorial design, a rotatable composite central design was designed to further assess the influence of the selected factors and to optimize the conditions for obtaining furfural. The experimental range was changed to shorter times (0.5-1 min) and lower $\mathrm{FeCl}_{3}$ concentrations (0.05-1 M), and the temperature range was reduced to a shorter one (190-200 ${ }^{\circ} \mathrm{C}$ ). The results (xylose consumption, furfural produced, yield, conversion, and selectivity) of the 25 experiments carried out according to the design conditions are shown in Table 3.

Table 3. Results (consumed xylose, furfural produced, yield, conversion, and selectivity) of the rotatable composite central design (duplicates of the star points +5 central points).

\begin{tabular}{|c|c|c|c|c|c|c|c|c|}
\hline Run & $\begin{array}{c}\text { A: } \mathrm{FeCl}_{3} \\
\text { (M) }\end{array}$ & $\begin{array}{l}\text { B: Time } \\
\text { (min) }\end{array}$ & $\begin{array}{c}\text { C: Temp. } \\
\left({ }^{\circ} \mathrm{C}\right)\end{array}$ & $\begin{array}{c}\text { Consumed } \\
\text { Xylose (g/L) }\end{array}$ & $\begin{array}{c}\text { Furfural } \\
(\mathrm{g} / \mathrm{L})\end{array}$ & $\begin{array}{l}\text { Yield } \\
(\%)\end{array}$ & $\begin{array}{c}\text { Conversion } \\
(\%)\end{array}$ & $\begin{array}{c}\text { Selectivity } \\
(\%)\end{array}$ \\
\hline 1 & 0.040 & 0.75 & 195 & 21.24 & 8.73 & 45.39 & 70.68 & 64.22 \\
\hline 4 & 0.05 & 0.5 & 200 & 25.43 & 10.04 & 52.07 & 84.40 & 61.69 \\
\hline 5 & 0.05 & 1 & 190 & 20.31 & 8.11 & 41.87 & 67.14 & 62.36 \\
\hline 6 & 0.1 & 1 & 200 & 28.88 & 10.32 & 53.35 & 95.54 & 55.84 \\
\hline 8 & 0.075 & 0.75 & 202.07 & 28.45 & 10.76 & 55.78 & 94.37 & 59.11 \\
\hline 9 & 0.075 & 0.75 & 187.93 & 19.07 & 7.64 & 39.55 & 63.15 & 62.63 \\
\hline 11 & 0.1 & 0.5 & 200 & 27.97 & 10.30 & 53.35 & 92.68 & 57.56 \\
\hline 12 & 0.040 & 0.75 & 195 & 22.05 & 8.99 & 46.64 & 73.18 & 63.73 \\
\hline 14 & 0.110 & 0.75 & 195 & 26.64 & 9.61 & 49.69 & 88.22 & 56.33 \\
\hline 20 & 0.075 & 0.40 & 195 & 22.31 & 8.97 & 46.68 & 74.31 & 62.82 \\
\hline 21 & 0.1 & 0.5 & 190 & 20.73 & 8.06 & 41.71 & 68.63 & 60.78 \\
\hline 22 & 0.05 & 1 & 200 & 26.09 & 10.18 & 52.67 & 86.40 & 60.95 \\
\hline 23 & 0.075 & 0.75 & 202.07 & 27.28 & 10.50 & 54.41 & 90.50 & 60.12 \\
\hline 25 & 0.075 & 1.10 & 195 & 26.06 & 9.86 & 51.05 & 86.35 & 59.12 \\
\hline 3 & 0.075 & 0.75 & 195 & 25.08 & 9.73 & 50.27 & 82.91 & 60.63 \\
\hline 10 & 0.075 & 0.75 & 195 & 25.05 & 9.49 & 49.08 & 82.94 & 59.18 \\
\hline 13 & 0.075 & 0.75 & 195 & 24.73 & 9.53 & 49.54 & 82.30 & 60.19 \\
\hline 16 & 0.075 & 0.75 & 195 & 24.50 & 9.91 & 51.33 & 81.20 & 63.22 \\
\hline 24 & 0.075 & 0.75 & 195 & 23.54 & 9.18 & 47.56 & 78.06 & 60.93 \\
\hline
\end{tabular}

The initial concentration of xylose was maintained at around $30 \mathrm{~g} / \mathrm{L}$, resulting in this design displaying higher consumption values than those in the factorial design, ranging from 15.57 to $28.88 \mathrm{~g} / \mathrm{L}$ or conversion of between 51.85 and $95.54 \%$. As for the furfural obtained, values between 6.37 and $10.76 \mathrm{~g} / \mathrm{L}$ were obtained, which represents a yield of 33.16 and $55.78 \%$, respectively, a shorter range than in the factorial design and higher on average. Finally, the selectivity showed values between 55.84 and $66.23 \%$, being on average around $61 \%$, compared with the factorial design where it was around $46 \%$.

For the analysis of the influence on the responses (yield, conversion and selectivity) of the factors studied (concentration of $\mathrm{FeCl}_{3}$, time, and temperature), the results were evaluated using the response surface methodology and modelled according to a quadratic model. The models obtained in coded and real terms together with the $p$-value, $R^{2}$, coefficient of variation $(\mathrm{CV})$, and standard deviation (SD) are shown in Table 4 . The three models show $R^{2}$ surpassing 0.91 , yield and conversion above $0.97(97 \%$ of the change is produced by the factors studied), and a CV in all cases below $2.5 \%$ (below 1.3 in the case of selectivity), that is, good values that allow us to use the models obtained for analysis. 
Table 4. Models in coded and real terms obtained for performance, conversion, and selectivity in the rotatable composite central design. $\mathrm{A}=$ concentration of $\mathrm{FeCl}_{3}, \mathrm{~B}=$ time, and $\mathrm{C}=$ temperature.

\begin{tabular}{|c|c|c|c|c|c|}
\hline Response & Model (Coded and Real Terms) & $p$-Value & $R^{2}$ & CV (\%) & SD (\%) \\
\hline Yield (\%) & $\begin{array}{c}(\text { Coded })=49.10+1.98 \cdot \mathrm{A}+2.15 \cdot \mathrm{B}+5.57 \cdot \mathrm{C}- \\
2.06 \cdot \mathrm{AC} \\
-2.27 \cdot \mathrm{BC}-0.54 \cdot \mathrm{A}^{2}-1.09 \cdot \mathrm{C}^{2} \\
(\text { Real })=-2345.52+3423.72 \cdot \mathrm{A}+362.70 \cdot \mathrm{B}+ \\
20.67 \cdot \mathrm{C}-16.48 \cdot \mathrm{AC}-1.82 \cdot \mathrm{BC}-871.20 \cdot \mathrm{A}^{2}- \\
0.04 \cdot \mathrm{C}^{2}\end{array}$ & $<0.0001$ & 0.970 & 2.38 & 1.14 \\
\hline Conversion $(\%)$ & $\begin{array}{c}(\text { Coded })=80.34+5.55 \cdot A+4.41 \cdot B+11.20 \cdot C- \\
1.30 \cdot A C-2.50 \cdot B C-1.78 \cdot C^{2} \\
(\text { Real })=3533.74+2246.99 \cdot A+406.90 \cdot B+ \\
32.25 \cdot C-10.38 \cdot A C-2.00 \cdot B C-0.07 \cdot C^{2}\end{array}$ & $<0.0001$ & 0.977 & 2.46 & 1.95 \\
\hline Selectivity (\%) & $\begin{array}{l}(\text { Coded })=60.49-2.23 \cdot \mathrm{A}-1.19 \cdot \mathrm{B}-1.07 \cdot \mathrm{C} \\
(\text { Real })=112.51-89.22 \cdot \mathrm{A}-4.74 \cdot \mathrm{B}-0.21 \cdot \mathrm{C}\end{array}$ & $<0.0001$ & 0.911 & 1.26 & 0.77 \\
\hline
\end{tabular}

The most influential factor in yield is temperature, given its higher coded coefficient of 5.57, followed by time and $\mathrm{FeCl}_{3}$ concentration with similar coefficients of 2.15 and 1.98, respectively. As for the interactions between factors, it can be seen that the yield at a high temperature varies little with the concentration of $\mathrm{FeCl}_{3}$, being slightly higher at an intermediate concentration owing to the slight curvature it presents (quadratic term, $\mathrm{A}^{2}$ ), while at a low temperature, the yield increases with the concentration of $\mathrm{FeCl}_{3}$ (Figure 3a). In the interaction with time, the behaviour is similar to that already described; the performance decreases in a negligible way with the increase of time at a high temperature, while at a low temperature, it increases with time (Figure 3b). The yield is higher at a high temperature for both interactions. The conversion and the yield have similar behaviour in front of the studied factors, as can be seen in the obtained models (Table 4) and the response surfaces (Figure 3), sharing the temperature as the most influential factor. Analyzing more in detail, the conversion increases with the increase of $\mathrm{FeCl}_{3}$ concentration, as well as with the increase of time, with this increase being more accentuated at low temperatures in both cases (Figure 3c,d). At a high temperature, the highest conversion values occur, and it is at this point that the increase in time has little influence on the increase in conversion (Figure 3d).

Selectivity shows different behaviour than that found in yield and conversion (Figure 3). Selectivity has, as its most influential factor, the concentration of $\mathrm{FeCl}_{3}$, followed by time and temperature at a considerable distance, according to the values of their coefficients of 2.23, 1.19, and 1.07, respectively (Table 4). Furthermore, in the selectivity model, only the linear terms were significant and all of them have a negative sign, which indicates that the lowest conditions of the factors are going to be the most favourable ones.

Table 5 shows the results of the best conditions and the values obtained from the different responses (performance, conversion, and selectivity) for different optimization proposals, giving the same weight to the responses in the case of multiple optimizations. The highest value of selectivity would be $64.98 \%$, and would be obtained under the lowest conditions of the design, that is, $190{ }^{\circ} \mathrm{C},\left[\mathrm{FeCl}_{3}\right]=0.05 \mathrm{M}$, and $0.5 \mathrm{~min}$. On the contrary, the highest conversion value would be obtained under the highest design conditions, that is, $200{ }^{\circ} \mathrm{C},\left[\mathrm{FeCl}_{3}\right]=0.1 \mathrm{M}$, and $1 \mathrm{~min}$, with a value of $95.93 \%$. The highest yield value, $53.71 \%$, is obtained at $200{ }^{\circ} \mathrm{C},\left[\mathrm{FeCl}_{3}\right]=0.07 \mathrm{M}$, and $0.5 \mathrm{~min}$, a value close to that obtained under the conditions of maximizing conversion, $52.84 \%$; on the contrary, the conversion and selectivity values are more distant. 


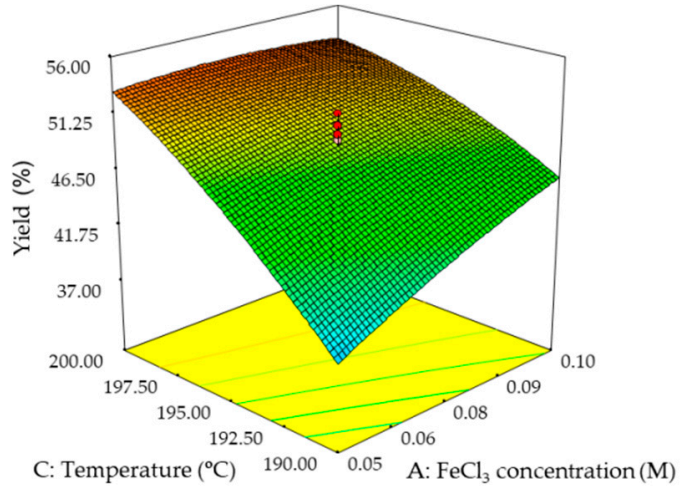

(a)

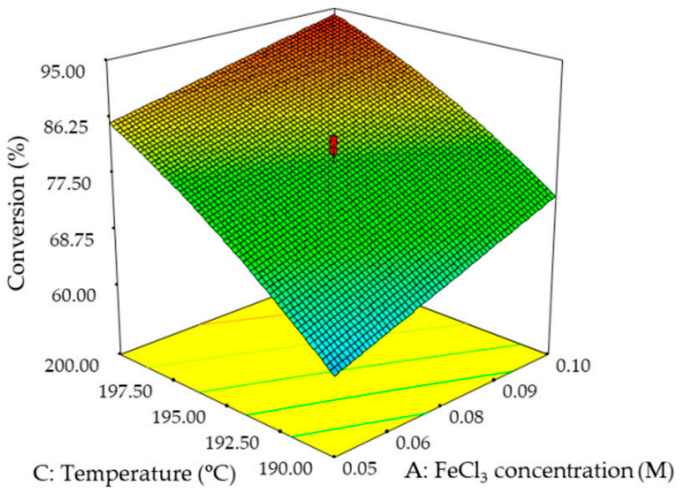

(c)

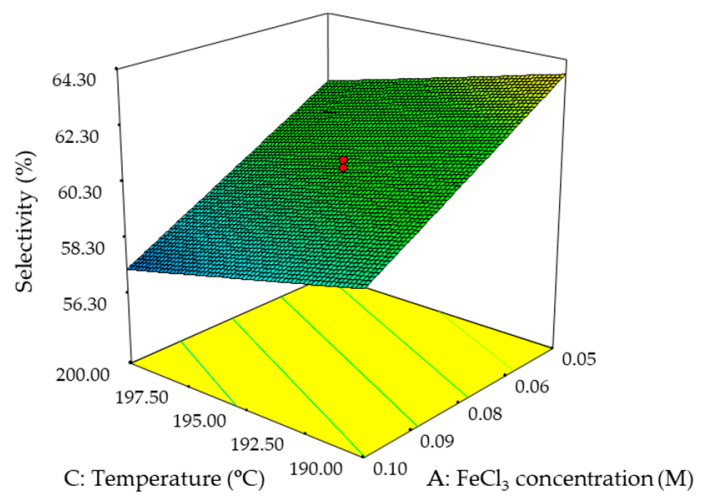

(e)

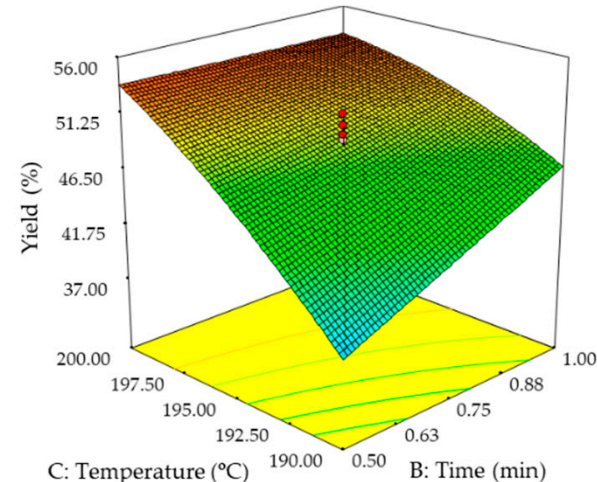

(b)

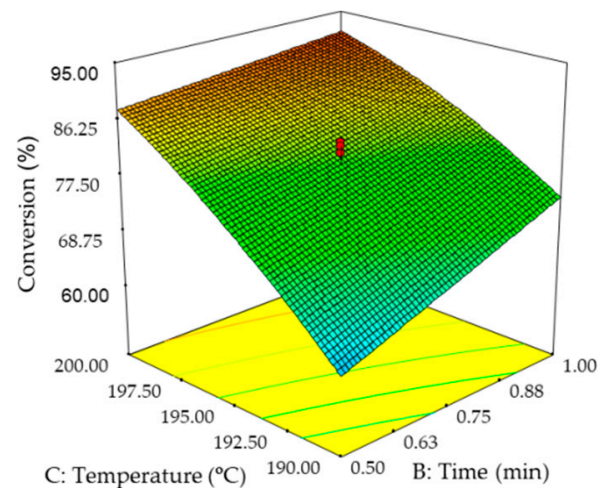

(d)

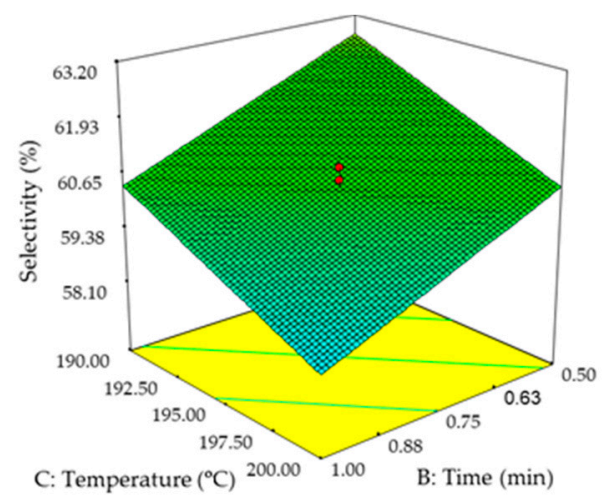

(f)

Figure 3. Response surfaces obtained for the composite central design: (a) influence of $\mathrm{FeCl}_{3}$ concentration and temperature on yield; (b) influence of time and temperature on yield; (c) influence of $\mathrm{FeCl}_{3}$ concentration and temperature on conversion; (d) influence of time and temperature on conversion; (e) influence of $\mathrm{FeCl}_{3}$ concentration and temperature on selectivity; (f) influence of time and temperature on selectivity. 
Table 5. Results of the optimization of the rotatable composite central design.

\begin{tabular}{|c|c|c|c|c|c|c|}
\hline Maximise & $\begin{array}{c}\mathrm{A}: \mathrm{FeCl}_{3} \\
\text { (M) }\end{array}$ & $\begin{array}{l}\text { B: Time } \\
\text { (min) }\end{array}$ & $\begin{array}{l}\text { C: Temp. } \\
\left({ }^{\circ} \mathrm{C}\right)\end{array}$ & $\begin{array}{l}\text { Yield } \\
(\%)\end{array}$ & $\begin{array}{c}\text { Conversion } \\
(\%)\end{array}$ & $\begin{array}{c}\text { Selectivity } \\
\text { (\%) }\end{array}$ \\
\hline Yield & 0.07 & 0.5 & 200 & 53.71 & 87.53 & 60.77 \\
\hline Conversion & 0.1 & 1 & 200 & 52.84 & 95.93 & 56.01 \\
\hline Selectivity & 0.05 & 0.5 & 190 & 33.44 & 53.61 & 64.98 \\
\hline Yield and selectivity & 0.05 & 0.5 & 200 & 53.24 & 83.59 & 62.84 \\
\hline Yield and conversion & 0.1 & 1 & 200 & 52.84 & 95.93 & 56.01 \\
\hline $\begin{array}{l}\text { Yield, conversion, } \\
\text { and selectivity }\end{array}$ & 0.05 & 0.5 & 200 & 53.24 & 83.59 & 62.84 \\
\hline $\begin{array}{l}\text { Star point experimental } \\
\text { average }\end{array}$ & 0.075 & 0.75 & 202.07 & 55.10 & 92.43 & 59.62 \\
\hline Predict star point & 0.075 & 0.75 & 202.07 & 54.81 & 92.62 & 58.98 \\
\hline Out of range & 0.05 & 0.5 & 210 & 64.35 & 99.34 & 60.70 \\
\hline Experimental out of range & 0.05 & 0.5 & 210 & 57.12 & 98.51 & 57.98 \\
\hline
\end{tabular}

Different optimizations have been made with more than one response, with yield as the common response in all cases. In the first of these, yield and selectivity have been jointly optimized, obtaining conditions of $200{ }^{\circ} \mathrm{C},\left[\mathrm{FeCl}_{3}\right]=0.05 \mathrm{M}$, and $0.5 \mathrm{~min}$ and values of $53.24 \%$ and $62.84 \%$, respectively, these values being very close to the individual optimums. In the second one, performance and conversion have been jointly optimized, obtaining conditions of $200{ }^{\circ} \mathrm{C},\left[\mathrm{FeCl}_{3}\right]=0.1 \mathrm{M}$, and $1 \mathrm{~min}$, resulting in these conditions having a greater difference compared with the individual performance optimum. Finally, in the case of the triple optimization of the three responses, the same conditions result as in the joint optimization of yield and selectivity, that is, $200{ }^{\circ} \mathrm{C},\left[\mathrm{FeCl}_{3}\right]=0.05 \mathrm{M}$, and $0.5 \mathrm{~min}$, with a final yield of $53.24 \%$. Reviewing the experimental results of the composite central design, it has been found that, under the conditions of one of the star points $\left(202.07^{\circ} \mathrm{C},\left[\mathrm{FeCl}_{3}\right]=0.075 \mathrm{M}\right.$, and $\left.0.75 \mathrm{~min}\right)$, the yield value obtained is on average $55.10 \%$ higher than that found under the optimum design conditions. The values of yield, conversion, and selectivity ( $54.81 \%, 92.62 \%$, and $58.98 \%$ ) according to the conditions of this star point were obtained with models resulting in errors of less than $1 \%$ (Table 5).

As can be seen in Figure 4, the efficiency and conversion show a good linear adjustment with $R^{2}=$ 0.92 , resulting in a $58 \%$ efficiency for the $100 \%$ conversion, higher than the value obtained in the star point conditions. Given the above, using the model obtained for the conversion, the temperature for which $100 \%$ would be obtained was sought. The concentration of $\mathrm{FeCl}_{3}$ was set at $0.05 \mathrm{M}$ and $0.5 \mathrm{~min}$ (triple optimum conditions) and a temperature of $210{ }^{\circ} \mathrm{C}$ was obtained (at $211^{\circ} \mathrm{C}$, the conversion is higher than $100 \%$ ). The conditions of $210^{\circ} \mathrm{C},\left[\mathrm{FeCl}_{3}\right]=0.05 \mathrm{M}$, and $0.5 \mathrm{~min}$ were tested experimentally, obtaining a conversion of $98.51 \%$, very close to that predicted by the model of $99.34 \%$. Under these conditions, a yield value of $57.12 \%$ was obtained, confirming the proposed hypothesis. This value is very close to $57.30 \%$, which would result from substituting the conversion value of $98.51 \%$ in the regression of Figure 4. If the experimental values and those predicted by the models for this temperature condition outside the range are compared, the experimental values of yield and selectivity are lower, by $11.24 \%$ and $4.47 \%$, respectively, and it can be said that the yield model cannot be used with temperatures so far from those in the initial range. 


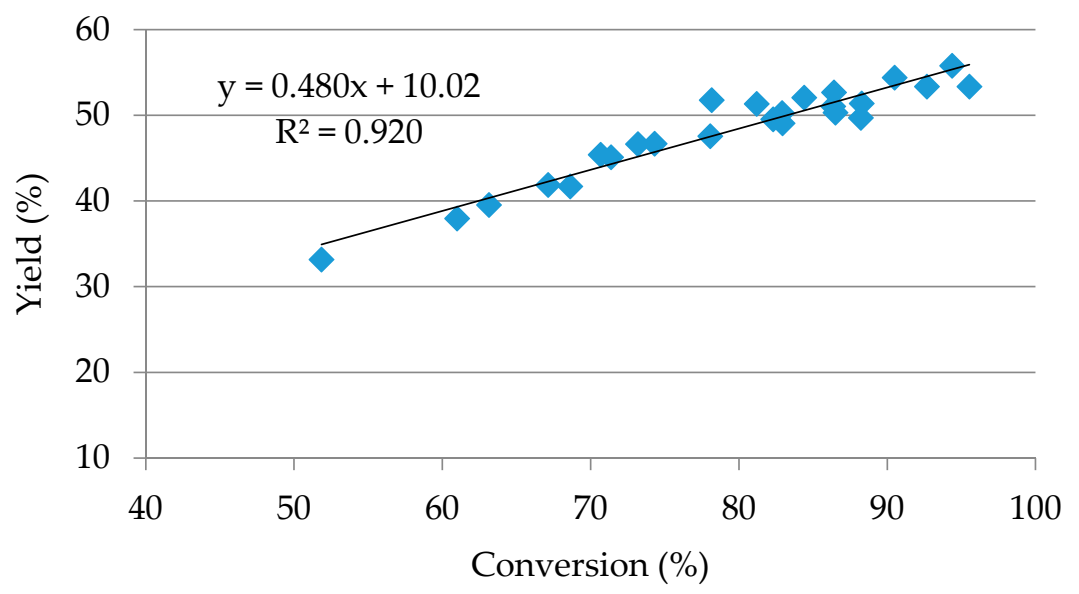

Figure 4. Linear performance regression versus conversion of the values of the composite central design.

\section{Discussion}

Different authors have made designs of experiments to study the influence of different factors and to determine the best conditions to obtain the maximum performance of furfural. In the cases that are going to be considered next, the response surface methodology and quadratic models were used as in our work.

Lamminpää et al. [28] studied four variables by a central composite circumscribed design using a preheating oven $\left(360-420^{\circ} \mathrm{C}\right)$ and a fluidized sand bath. The variables were time (20-40 min), temperature $\left(140-200^{\circ} \mathrm{C}\right)$, initial xylose concentration $(0.067-0.20 \mathrm{M})$, and formic acid concentration $(10-30 \% w / w)$. The design contained 29 experiments, including five central points. In this design, the authors obtained conversions ranging from $6.2 \%$ to $98.2 \%$ and selectivities from $42 \%$ to $73 \%$, values similar to those obtained in this work. Conversion and yield were mainly influenced positively by temperature and, as in our case, followed by acid concentration. The maximum yield value obtained was $65 \%$ at $200{ }^{\circ} \mathrm{C}, 20 \mathrm{~min}, 30 \mathrm{wt} \%$ of formic acid, and with an initial xylose concentration of $10 \mathrm{~g} / \mathrm{L}$. This yield in the same conditions, but increasing the initial xylose concentration to $30 \mathrm{~g} / \mathrm{L}$ (the same as in our work), drops to $56.8 \%$, very similar to the value obtained in our work of $57.1 \%$, although with a much shorter time of only $0.5 \mathrm{~min}$ in our case. The industrial process adopted by China with corncobs achieves around $50 \%$ yield with $3-4 \mathrm{wt} \%$ sulfuric acid at $153{ }^{\circ} \mathrm{C}$ for $5 \mathrm{~h}$ [9].

Yang et al. [27] also performed a central composite design in this case in a stainless steel autoclave, with an electric jacket, a constant initial xylose concentration of $80 \mathrm{~g} / \mathrm{L}$, and varying the proportion of water-o-nitrotoluene. The reaction temperature $\left(170-210^{\circ} \mathrm{C}\right)$, formic acid concentration $(5-25 \mathrm{~g} / \mathrm{L}$, $\left.\mathrm{pH}_{25}{ }^{\circ} \mathrm{C} 2.32-1.96\right)$, o-nitrotoluene volume percentage (20-80 vol\%), and residence time (40-200 min) were analyzed in the experimental design. The design consisted of 27 experiments, including three central points. The results included selectivities between 51.1 and $99.7 \%$ and yields between 20.3 and $71.2 \%$, which are higher than those obtained in the previous design and those presented in this work. Among the factors studied in this design, temperature and o-nitrotoluene percentage are the most influential, with time and formic acid concentration having a low influence on yield and selectivity. Both yield and selectivity present a maximum of around $190^{\circ} \mathrm{C}$. On the contrary, the increase of o-nitrotoluene percentage ( $0 \mathrm{vol} \%$ to $80 \mathrm{vol} \%)$ was positive in both yield and selectivity, with increases from about $30 \%$ to $70 \%$ and $70 \%$ to $99 \%$, respectively. The maximum furfural yield $(74 \%)$ and selectivity ( $86 \%$ ) were obtained in $75 \mathrm{~min}$ at $190^{\circ} \mathrm{C}$ for $20 \mathrm{~g} / \mathrm{L}$ formic acid concentration and $75 \mathrm{vol} \%$ o-nitrotoluene. This yield is higher than that obtained in our work, but the time is much higher, that is, $75 \mathrm{~min}$ compared with $0.5 \mathrm{~min}$, and it also uses an organic solvent from petroleum, which makes the process less sustainable. To reduce the reaction time, the authors added different halides $(\mathrm{NaCl}$, $\mathrm{KCl}, \mathrm{KBr}$, and $\mathrm{KI}$ ) with a concentration of $0.5 \mathrm{M}$, achieving an optimum time in $60 \mathrm{~min}$, or in other words, a reduction of $15 \mathrm{~min}$. This time is still far from that obtained in our work, even though it 
achieved a slight improvement in performance and selectivity, for example, with $\mathrm{NaCl}$, of $78 \%$ and $90 \%$, respectively.

Another type of design was used to study the effect of lignin on the production of furfural from xylose (30 g/L), at D-optimal design [29]. In the design, four variables were included: three quantitative variables, time $(20-80 \mathrm{~min})$, temperature $\left(160-180^{\circ} \mathrm{C}\right)$, and initial lignin concentration $(0-20 \mathrm{~g} / \mathrm{L})$; and one qualitative variable, the acid catalyst $(10 \% w / w)$ formic acid or $0.2 \% w / w$ sulfuric acid (initial $\mathrm{pH}$ similar). The design contained 26 experiments, including 3 central points, plus 4 extra points, for a total of 30 experiments. The xylose conversion varied from $12 \%$ to $90 \%$ with the formic acid and from $6 \%$ to $85 \%$ with the sulfuric acid, values somewhat lower than those obtained in our work. The furfural yield varied from $9 \%$ to $58 \%$ in $\mathrm{HCOOH}$ and from $4 \%$ to $53 \%$ in $\mathrm{H}_{2} \mathrm{SO}_{4}$, in the order of our work. The selectivities were $65-80 \%$ and $63-76 \%$ in $\mathrm{HCOOH}$ and $\mathrm{H}_{2} \mathrm{SO}_{4}$, respectively, higher than those obtained in our work, with the least variation between large and small values compared with the other responses. The most influential factors in yield are temperature and time in both $\mathrm{HCOOH}$ and $\mathrm{H}_{2} \mathrm{SO}_{4}$ cases. The difference in the influence of lignin is found to be more significant in the case of $\mathrm{H}_{2} \mathrm{SO}_{4}$ than in $\mathrm{HCOOH}$; for example, at $180^{\circ} \mathrm{C}$ in sulfuric acid, the yield is higher than $50 \%$ without lignin, but in the presence of $20 \mathrm{~g} / \mathrm{L}$ lignin, the yield is lower than $40 \%$, whereas in formic acid, the yield stays about the same, at around $62 \%$. The maximum yields are given at $180^{\circ} \mathrm{C}, 80 \mathrm{~min}$, and without lignin, with values around $64 \%$ and $56 \%$ with $\mathrm{HCOOH}$ and $\mathrm{H}_{2} \mathrm{SO}_{4}$, respectively, values in the order of those obtained in this work, but with a much longer time. The authors concluded that lignin affected furfural formation in two ways: (1) the lignin has an acid neutralization capacity (the maximum rise in $\mathrm{pH}$ was 0.13 units in formic acid and 0.23 units in sulfuric acid; time and temperature are insignificant parameters for the $\mathrm{pH}$ change response model), and (2) the lignin inhibits xylose dehydration into furfural (the neutralizing effect does not explain all of the decreases in conversion and yield, so some additional mechanism must be involved) [29]. Rasmussen et al. [30] concluded that there are at least three possible routes for furfural formation from xylose, and the reaction conditions determine which mechanism dominates.

\section{Overview of the Production of Furfural from Xylose}

Table 6 shows a varied representation of the processes used to produce furfural from xylose (maximize furfural yield) in monophase systems with green solvents, as in our case, to have processes without petroleum derivatives.

Among those green solvents are water, seawater, gamma-valerolactone (GVL), GVL-water, dimethyl sulfoxide (DMSO), N,N-dimethylacetamide (DMA), and some ionic liquids ([emin]Br, [emim] $\mathrm{HSO}_{4},[\mathrm{bmim}] \mathrm{PF}_{6}$ ) that are not chloride based as they are considered toxic and corrosive [31]. In most cases, some kind of catalyst was used to increase the reaction speed and improve the yield in furfural.

These catalysts can be both homogeneous and heterogeneous. Among the homogeneous catalysts are inorganic acids $\left(\mathrm{HCl}, \mathrm{H}_{2} \mathrm{SO}_{4}\right)$; organic acids (formic acid, maleic acid); salts $\left(\mathrm{FeCl}_{3}, \mathrm{SnCl}_{4}\right)$; heteropolyacid salts (MP34CsPW, $\mathrm{H}_{3} \mathrm{PW}_{12} \mathrm{O}_{40}(\mathrm{PW})$ ); a combination of mineral acid + salt ( $\mathrm{HCl}-\mathrm{NaCl}$, $\left.\mathrm{H}_{2} \mathrm{SO}_{4}-\mathrm{FeCl}_{3}\right)$, as in our case; or combinations of different salts $\left(\mathrm{CrCl}_{2}-\mathrm{LiBr}\right)$. Among the heterogeneous catalysts, we find zeolites (H-ZSM-5, H-Mordenite, H-Beta) or mesoporous acid-catalysts $\left(\mathrm{MSHS}_{-} \mathrm{SO}_{3} \mathrm{H}\right.$, Nafion 117). 
Table 6. Yield results of furfural production from xylose in green solvents in the monophase system.

\begin{tabular}{|c|c|c|c|c|c|c|}
\hline Xylose & Solvent & Catalyst & Temperature/Time & Heating & Furfural Yield (\%) & Ref. \\
\hline $30 \mathrm{~g} / \mathrm{L}=200 \mathrm{mM}$ & $\mathrm{H}_{2} \mathrm{O}$ & MSHS-SO ${ }_{3} \mathrm{H}(3.3 \mathrm{~g} / \mathrm{L})$ & $190^{\circ} \mathrm{C} / 1 \mathrm{~h}$ & Autoclave & 43.5 & [32] \\
\hline $10 \mathrm{wt} \%$ & $\mathrm{H}_{2} \mathrm{O}$ & H-ZSM-5 (catalyst-xylose ratio, $0.3 w / w$ ) & $200^{\circ} \mathrm{C} / 20 \mathrm{~min}$ & Autoclave & 46 & [33] \\
\hline $35 \mathrm{mM}$ & $\mathrm{H}_{2} \mathrm{O}$ & $\mathrm{HCl}(50 \mathrm{mM})-\mathrm{NaCl}(850 \mathrm{mM})$ & $200^{\circ} \mathrm{C} / 5 \mathrm{~min}$ & Oil bath & 81.3 & [14] \\
\hline $35 \mathrm{mM}$ & $\mathrm{H}_{2} \mathrm{O}$ & $\mathrm{HCl}(50 \mathrm{mM})-\mathrm{NaCl}(3.5 \mathrm{wt} \%=599 \mathrm{mM})$ & $200^{\circ} \mathrm{C} / 440 \mathrm{~s}(7.3 \mathrm{~min})$ & Microwave & 76 & [34] \\
\hline $740 \mathrm{mM}$ & $\mathrm{H}_{2} \mathrm{O}$ & $\mathrm{HCl}(100 \mathrm{mM})$ & $170^{\circ} \mathrm{C} / 30 \mathrm{~min}$ & Microwave & 40 & [17] \\
\hline $667 \mathrm{mM}$ & $\mathrm{H}_{2} \mathrm{O}$ & $\mathrm{HCl}(100 \mathrm{mM})$ & $180^{\circ} \mathrm{C} / 30 \mathrm{~min}$ & Microwave & 39 & [19] \\
\hline $67 \mathrm{mM}=10 \mathrm{~g} / \mathrm{L}$ & $\mathrm{H}_{2} \mathrm{O}$ & Maleic acid $(250 \mathrm{mM})$ & $200^{\circ} \mathrm{C} / 28 \mathrm{~min}$ & Microwave & 67 & [35] \\
\hline $57 \mathrm{mM}$ & $\mathrm{H}_{2} \mathrm{O}$ & Not used & $200{ }^{\circ} \mathrm{C} / 60 \mathrm{~min}$ & Microwave & 49 & [36] \\
\hline $30 \mathrm{~g} / \mathrm{L}$ & $\mathrm{H}_{2} \mathrm{O}$ & $\mathrm{H}_{2} \mathrm{SO}_{4}(2 \% w / v)-\mathrm{FeCl}_{3}(0.05 \mathrm{M})$ & $210^{\circ} \mathrm{C} / 0.5 \mathrm{~min}$ & Microwave & 57.1 & Present study \\
\hline $67 \mathrm{mM}$ & $\mathrm{H}_{2} \mathrm{O}$ & Formic acid (30 wt $\%)$ & $200^{\circ} \mathrm{C} / 20 \mathrm{~min}$ & $\begin{array}{l}\text { Oven preheating }\left(360-420^{\circ} \mathrm{C}\right) \\
\text { and a fluidized sand bath }\end{array}$ & 65 & [28] \\
\hline $200 \mathrm{mM}$ & $\mathrm{H}_{2} \mathrm{O}$ & Formic acid $(30 \mathrm{wt} \%)$ & $200{ }^{\circ} \mathrm{C} / 20 \mathrm{~min}$ & $\begin{array}{l}\text { Oven preheating }\left(360-420^{\circ} \mathrm{C}\right) \\
\text { and a fluidized sand bath }\end{array}$ & 56.8 & [28] \\
\hline $30 \mathrm{~g} / \mathrm{L}$ & $\mathrm{H}_{2} \mathrm{O}$ & Formic acid $(30 \mathrm{wt} \%)$ & $180^{\circ} \mathrm{C} / 80 \mathrm{~min}$ & $\begin{array}{l}\text { Oven preheating }\left(360-420^{\circ} \mathrm{C}\right) \\
\text { and a fluidized sand bath }\end{array}$ & $\sim 63.8$ & [29] \\
\hline $30 \mathrm{~g} / \mathrm{L}$ & $\mathrm{H}_{2} \mathrm{O}$ & $\mathrm{H}_{2} \mathrm{SO}_{4}(0.2 \mathrm{wt} \%)$ & $180^{\circ} \mathrm{C} / 80 \mathrm{~min}$ & $\begin{array}{l}\text { Oven preheating }\left(360-420^{\circ} \mathrm{C}\right) \\
\text { and a fluidized sand bath }\end{array}$ & $\sim 56.2$ & [29] \\
\hline $18 \mathrm{wt} \%$ & $\mathrm{H}_{2} \mathrm{O}$ & $\mathrm{H}_{2} \mathrm{SO}_{4}(20 \mathrm{mM})$ & $250^{\circ} \mathrm{C} / 1 \mathrm{~min}$ & $\begin{array}{c}\text { Supercritical flow reactor } \\
\text { system }\end{array}$ & 64 & [37] \\
\hline $50 \mathrm{mM}$ & $\begin{array}{l}\text { Seawater (salts } \\
\quad(26,46 \mathrm{~g} / \mathrm{kg})\end{array}$ & $\mathrm{HCl}(50 \mathrm{mM})$ & $200^{\circ} \mathrm{C} / 10 \mathrm{~min}$ & Oil bath & 71.7 & [38] \\
\hline $150 \mathrm{mM}$ & GVL & $\mathrm{H}_{2} \mathrm{SO}_{4}$ & $175^{\circ} \mathrm{C}$ & Not specified & 75 & [39] \\
\hline $2.4 \mathrm{wt} \%$ & GVL & $\mathrm{FeCl}_{3} \cdot 6 \mathrm{H}_{2} \mathrm{O}(0.6 \mathrm{wt} \%)$ & $180^{\circ} \mathrm{C} / 9 \mathrm{~min}$ & Oil bath & 83.6 & [13] \\
\hline $2 w t \%$ & GVL- $\mathrm{H}_{2} \mathrm{O}\left(10 \mathrm{wt} \% \mathrm{H}_{2} \mathrm{O}\right)$ & $\mathrm{H}_{2} \mathrm{SO}_{4}(0.05 \mathrm{M})$ & $170{ }^{\circ} \mathrm{C} / 15 \mathrm{~min}$ & Oil bath & 87 & [40] \\
\hline $2 w t \%$ & GVL- $\mathrm{H}_{2} \mathrm{O}\left(10 \mathrm{wt} \% \mathrm{H}_{2} \mathrm{O}\right)$ & H-Mordenite & $175^{\circ} \mathrm{C} / 2 \mathrm{~h}$ & Oil bath & 81 & [41] \\
\hline $2 w t \%$ & GVL- $\mathrm{H}_{2} \mathrm{O}\left(10 \mathrm{wt} \% \mathrm{H}_{2} \mathrm{O}\right)$ & H-Beta $(3.75$ wt $\%)$ & $160{ }^{\circ} \mathrm{C} / 1 \mathrm{~h}$ & Oil bath & 71 & [40] \\
\hline $200 \mathrm{mM}$ & DMSO & H-Mordenite $(100 \mathrm{~g} / \mathrm{L})$ & $140^{\circ} \mathrm{C} / 4 \mathrm{~h}$ & Autoclave & 39 & [42] \\
\hline $200 \mathrm{mM}$ & DMSO & MP34CsPW (30 g/L) & $140{ }^{\circ} \mathrm{C} / 4 \mathrm{~h}$ & Oil bath & 45 & [3] \\
\hline $200 \mathrm{mM}$ & DMSO & $\mathrm{H}_{3} \mathrm{PW}_{12} \mathrm{O}_{40}(\mathrm{PW})(20 \mathrm{~g} / \mathrm{L})$ & $140^{\circ} \mathrm{C} / 4 \mathrm{~h}$ & Oil bath & 67 & [43] \\
\hline $9.1 \mathrm{wt} \%$ & DMSO & Nafion 117 (20 wt $\%$ of initial xylose) & $150^{\circ} \mathrm{C} / 2 \mathrm{~h}$ & Oil bath & 60 & [44] \\
\hline $10 \mathrm{wt} \%$ & DMSO & $\mathrm{HCl}(0.1 \mathrm{M})-\mathrm{Sn}$-beta & $110^{\circ} \mathrm{C} / 3 \mathrm{~h}$ & Not specified & 14.3 & [45] \\
\hline $10 \mathrm{wt} \%$ & DMA & $\mathrm{CrCl}_{2}(6 \mathrm{~mol} \%$ of $x y l o s e)-\mathrm{LiBr}(10 \mathrm{wt} \%)$ & $100{ }^{\circ} \mathrm{C} / 4 \mathrm{~h}$ & Oil bath & 56 & [46] \\
\hline $20 \mathrm{wt} \%$ & [emin] $\mathrm{Br}$ & $\mathrm{SnCl}_{4}$ (10 mol\% of xylose) & $130^{\circ} \mathrm{C} / 1 \mathrm{~h}$ & Oil bath & 71.1 & [15] \\
\hline $100 \mathrm{~g} / \mathrm{L}$ & {$[\mathrm{emim}] \mathrm{HSO}_{4}$} & Not used & $100^{\circ} \mathrm{C} / 30 \mathrm{~min}$ & Oil bath & 62 & [47] \\
\hline $37.5 \mathrm{~g} / \mathrm{L}$ & {$[\mathrm{bmim}] \mathrm{PF}_{6}$} & PEG-OSO ${ }_{3} \mathrm{H}(50 \mathrm{mM})-\mathrm{MnCl}_{2}(75 \mathrm{mM})$ & $120^{\circ} \mathrm{C} / 18 \mathrm{~min}$ & Not specified & 75 & [48] \\
\hline
\end{tabular}


There is also a combination of homogeneous and heterogeneous catalysts, such as inorganic acid + zeolite (HCl-Sn-beta) or a polymer bound an acid + salt $\left(\mathrm{PEG}-\mathrm{OSO}_{3} \mathrm{H}-\mathrm{MnCl}_{2}\right)$. As for the forms of heating used, they could be grouped into two large groups, conventional ones like autoclave, oil bath or oven preheating $\left(360-420^{\circ} \mathrm{C}\right)$, and a fluidized sand bath; and non-conventional ones, such as microwaves (our case) and supercritical systems.

The initial xylose concentration used (Table 6) shows a wide range from just $5 \mathrm{~g} / \mathrm{L}$ to $200 \mathrm{~g} / \mathrm{L}$, with the average being around $50 \mathrm{~g} / \mathrm{L}$ and the median of $30 \mathrm{~g} / \mathrm{L}$, which coincides with the value used in this work. The temperatures used range from $100{ }^{\circ} \mathrm{C}$ to $250{ }^{\circ} \mathrm{C}$, with the average being around $170{ }^{\circ} \mathrm{C}$ and the median being $180^{\circ} \mathrm{C}$. If only microwave heating is taken into account, the temperature range is shorter, $170-210^{\circ} \mathrm{C}$, where the average is just over $193^{\circ} \mathrm{C}$ and the median is $200{ }^{\circ} \mathrm{C}$, showing that optimum temperatures with microwaves are higher when using other forms of heating. The times used also show a wide range from $0.5 \mathrm{~min}$ (this work) to $240 \mathrm{~min}$, with an average of $70 \mathrm{~min}$, while the average in the case of using microwaves around a third is about $25 \mathrm{~min}$, showing itself as a faster process and one that would also save energy [17,34]. The yields obtained range from $14 \%$ to $87 \%$, with the average being around $61 \%$; meanwhile, taking into account only microwave heating, this average would be around $55 \%$; the value obtained in this work of $57 \%$ is in the order of these averages. If all the values shown in Table 6 are analyzed to see how they affect the furfural yield, the following is found: the highest values are given to short times (less than $20 \mathrm{~min}$ ), high temperatures $\left(180-200^{\circ} \mathrm{C}\right.$ ) (same trend found in this work), and the increase of the initial xylose concentration having a slight negative effect.

With the idea of being able to increase the yield of furfural, one of the proposals is the biphasic systems in such a way that furfural is produced in one phase and is selectively transferred to the insoluble organic phase, avoiding its degradation and displacing the reaction balance. Several authors have reported that they have doubled the performance of furfural when using a biphase system (with methyl isobutyl ketone (MIBK) or cyclopentylmethyl ether (CPME)) versus a monophase system with water only $[10,17,49]$. Table 7 shows some biphase processes with green solvents for the production of furfural. 
Table 7. Yield results of furfural production from xylose in green solvents in biphase systems.

\begin{tabular}{|c|c|c|c|c|c|c|}
\hline Xylose & Solvent & Catalyst & Temperature/Time & Heating & $\begin{array}{l}\text { Furfural } \\
\text { Yield (\%) }\end{array}$ & Ref \\
\hline $1.85 \mathrm{wt} \%$ & $\begin{array}{c}\text { [bmim }] \mathrm{HSO}_{4} \text {-MIBK } \\
(1: 4.4, w / w)\end{array}$ & Not used & $140^{\circ} \mathrm{C} / 4 \mathrm{~h}$ & Oil bath & 80.3 & {$[50]$} \\
\hline $\begin{array}{c}400 \mathrm{mmol} / \mathrm{L} \\
\mathrm{H}_{2} \mathrm{O}\end{array}$ & $\mathrm{H}_{2} \mathrm{O}-2 \mathrm{MTHF}(1: 1, v / v)$ & $\begin{array}{c}\mathrm{FeCl}_{3}(80 \mathrm{mM})-\mathrm{NaCl} \\
(20 \mathrm{wt} \%)\end{array}$ & $140^{\circ} \mathrm{C} / 4 \mathrm{~h}$ & Oil bath & 71 & [51] \\
\hline $\begin{array}{l}4 \mathrm{wt} \% \mathrm{H}_{2} \mathrm{O} \\
\text { phase }\end{array}$ & $\begin{array}{c}\mathrm{H}_{2} \mathrm{O}-\mathrm{CPME} \\
v / v)\end{array}$ & $\begin{array}{c}\mathrm{H}_{2} \mathrm{SO}_{4}\left(1 \mathrm{wt} \% \mathrm{H}_{2} \mathrm{O}\right. \\
\text { phase)-NaCl (40 wt } \% \\
\left.\mathrm{H}_{2} \mathrm{O} \text { phase }\right)\end{array}$ & $170^{\circ} \mathrm{C} / 100 \mathrm{~min}$ & Oil bath & 100 & [52] \\
\hline $\begin{array}{c}1.25 \mathrm{~mol} / \mathrm{L} \\
\mathrm{H}_{2} \mathrm{O}\end{array}$ & $\mathrm{H}_{2} \mathrm{O}-\mathrm{CPME}(1: 3, v / v)$ & $\begin{array}{c}\mathrm{FeCl}_{3}(5.08 \mathrm{~g} / \mathrm{L})-\mathrm{NaCl} \\
(18.13 \mathrm{~g} / \mathrm{L})\end{array}$ & $170^{\circ} \mathrm{C} / 20 \mathrm{~min}$ & Microwave & 74 & [10] \\
\hline $1 \mathrm{~mol} / \mathrm{L} \mathrm{H}_{2} \mathrm{O}$ & $\mathrm{H}_{2} \mathrm{O}-\mathrm{CPME}(1: 3, v / v)$ & $\begin{array}{c}\mathrm{NaCl}(23.75 \mathrm{~g} / \mathrm{L})-\mathrm{Nafion} \\
\mathrm{NR} 50(23.75 \mathrm{~g} / \mathrm{L})\end{array}$ & $170^{\circ} \mathrm{C} / 40 \mathrm{~min}$ & Microwave & 80 & [49] \\
\hline $200 \mathrm{~g} / \mathrm{L} \mathrm{H}_{2} \mathrm{O}$ & $\mathrm{H}_{2} \mathrm{O}-\mathrm{DMSO}(1: 1, v / v)$ & $\begin{array}{l}\mathrm{SnCl}_{4} \text { (catalyst/xylose } \\
\text { molar ratio } 0.5)\end{array}$ & $130^{\circ} \mathrm{C} / 6 \mathrm{~h}$ & Oil bath & 63 & [53] \\
\hline $\begin{array}{c}10 \mathrm{wt} \% \mathrm{H}_{2} \mathrm{O} \\
\text { phase }\end{array}$ & $\begin{array}{l}\mathrm{H}_{2} \mathrm{O}-\mathrm{DMSO}-\mathrm{SBP} \\
(5: 1: 5, v / v / v)\end{array}$ & $\begin{array}{c}\text { Sn-MMT } \\
\text { (xylose-catalyst, } 5: 1 \\
w / w)-\mathrm{NaCl} \text { (satured } \\
\text { solution, aprox. } \\
36 \mathrm{~g} / 100 \mathrm{~g} \text { of } \mathrm{H}_{2} \mathrm{O} \text { ) }\end{array}$ & $180^{\circ} \mathrm{C} / 30 \mathrm{~min}$ & Autoclave & 76.8 & [54] \\
\hline $\begin{array}{c}1 \mathrm{~g} / \mathrm{L}, 5 \mathrm{~mL} \\
\mathrm{H}_{2} \mathrm{O}\end{array}$ & $\mathrm{H}_{2} \mathrm{O}-\mathrm{MIBK}(1.5: 8, v / v)$ & $\begin{array}{c}{[\mathrm{Sbmim}] \mathrm{HSO}_{4}} \\
\left(0.5 \mathrm{~g} / 1.5 \mathrm{~mL} \mathrm{H}_{2} \mathrm{O}\right)\end{array}$ & $150^{\circ} \mathrm{C} / 25 \mathrm{~min}$ & Autoclave & 91.4 & [55] \\
\hline $\begin{array}{c}740 \mathrm{mmol} / \mathrm{L} \\
\mathrm{H}_{2} \mathrm{O}\end{array}$ & $\mathrm{H}_{2} \mathrm{O}-\mathrm{MIBK}(1: 1, w / w)$ & $\mathrm{HCl}\left(0.1 \mathrm{~mol} / \mathrm{L} \mathrm{H}_{2} \mathrm{O}\right)$ & $170^{\circ} \mathrm{C} / 30 \mathrm{~min}$ & Microwave & 80 & [17] \\
\hline $10 \mathrm{wt} \%$ of $\mathrm{H}_{2} \mathrm{O}$ & $\mathrm{H}_{2} \mathrm{O}-\mathrm{THF}(1: 2, w / w)$ & $\begin{array}{l}{\left[\mathrm{SbPy}^{\mathrm{SbF}} \mathrm{BF}_{4}(100 \mathrm{wt} \% \text { of }\right.} \\
\text { initial xylose })\end{array}$ & $180^{\circ} \mathrm{C} / 1 \mathrm{~h}$ & Microwave & 85 & {$[56]$} \\
\hline $\begin{array}{c}250 \mathrm{mmol} / \mathrm{L} \\
\mathrm{H}_{2} \mathrm{O}\end{array}$ & $\mathrm{H}_{2} \mathrm{O}-\mathrm{THF}(1: 3, v / v)$ & $\begin{array}{c}\mathrm{AlCl}_{3}-6 \mathrm{H}_{2} \mathrm{O} \\
(25 \mathrm{mM})-\mathrm{NaCl}(1.5 \mathrm{M})\end{array}$ & $140^{\circ} \mathrm{C} / 45 \mathrm{~min}$ & Microwave & 75 & [57] \\
\hline
\end{tabular}

MIBK, methyl isobutyl ketone; 2MTHF, 2 methyltetrahydrofuran; CPME, cyclopentylmethyl ether; DMSO, dimethyl sulfoxide; SBP, 2-s-butilfenol; THF, tetrahydrofuran.

In these processes, mainly water, but also ionic liquids ([bmim] $\mathrm{HSO}_{4}$ ) were used as the reaction phase solvents and organic cosolvents as follows: methyl isobutyl ketone (MIBK), 2-methyltetrahydrofuran (2MTHF), cyclopentylmethyl ether (CPME), dimethyl sulfoxide (DMSO), 2-s-butilfenol (SBP), and tetrahydrofuran (THF). In most cases, some kind of catalyst was used, either a homogeneous catalyst such as inorganic acids $(\mathrm{HCl})$, salts $\left(\mathrm{SnCl}_{4}\right)$, a combination of mineral acid + salt $\left(\mathrm{H}_{2} \mathrm{SO}_{4}-\mathrm{NaCl}\right)$, combinations of different salts $\left(\mathrm{FeCl}_{3}-\mathrm{NaCl}, \mathrm{AlCl}_{3}-\mathrm{NaCl}\right)$ or ionic liquids ([Sbmim] $\mathrm{HSO}_{4}$, [SbPy] $\mathrm{BF}_{4}$ ); or a combination of heterogeneous and homogeneous (Sn-MMT-NaCl, Nafion NR50-NaCl). As for the forms of heating used, the processes could be grouped into conventional ones, including autoclave and oil bath, and non-conventional ones such as microwaves. The initial xylose concentration assayed shows a very wide range from $18.5 \mathrm{~g} / \mathrm{L}$ to more than $600 \mathrm{~g} / \mathrm{L}$, with the average being around $150 \mathrm{~g} / \mathrm{L}$, or around $120 \mathrm{~g} / \mathrm{L}$ in the case of microwave heating. The range of temperature was from $130{ }^{\circ} \mathrm{C}$ to $180{ }^{\circ} \mathrm{C}$, with the median being $170{ }^{\circ} \mathrm{C}$, the same median value as in the case of microwave heating. Concerning the values of the process time, a wide range from $20 \mathrm{~min}$ to $360 \mathrm{~min}$ was used, with an average close to $110 \mathrm{~min}$, with the average in the case of using microwaves around a third being about $39 \mathrm{~min}$.

Microwave-assisted processes were faster than conventional heated processes, as in the case of monophasic, and also more selective [34]. The yields obtained ranged from $63 \%$ to $100 \%$, with the average being around $80 \%$, with the average value being very similar with microwave heating, at $79 \%$. The average value obtained in biphasic processes is $30 \%$ higher than the average value obtained in monophasic processes ( $80 \%$ versus $60 \%$ ). If all the values shown in Table 7 were analyzed to see how they affected the furfural yield, it is found that the highest values were given at high temperatures $\left(170-180^{\circ} \mathrm{C}\right.$ ) and at short times (less than $60 \mathrm{~min}$ ), while the initial xylose concentration had no apparent influence. 


\section{Materials and Methods}

\subsection{Chemical Reagents}

Xylose was purchased from Fagron (Terrassa, Spain); $\mathrm{FeCl}_{3}$ hexahydrate (99\%) was purchased from Emsure (Darmstadt, Germany); $\mathrm{H}_{2} \mathrm{SO}_{4}$ (98\%) was purchased from Honeywell Fluka (Seelze, Germany). All materials were used without further purification. Aqueous solutions were prepared with deionized $\mathrm{H}_{2} \mathrm{O}$.

\subsection{General Procedure for Dehydration Treatment}

All experiments were conducted using a microwave reactor (Anton Paar Monowave 400, Graz, Austria). The xylose and the catalysts in different concentrations were charged in the $10 \mathrm{~mL}$ glass vessel. The reaction volume was $4 \mathrm{~mL}$; the xylose concentration was $30 \mathrm{~g} / \mathrm{L}$; and the catalysts used were $\mathrm{H}_{2} \mathrm{SO}_{4}$ at $2 \% w / v$ acting as Brønsted acid and $\mathrm{FeCl}_{3}$ as Lewis acid, with a variable concentration $[10,13]$.

The heating dynamic followed was to heat the sample to the set temperature in 2 min, maintaining the temperature for the experiment time, and cooling down to $40{ }^{\circ} \mathrm{C}$ with compressed air. The magnetic agitation during the heating and maintenance was $600 \mathrm{rpm}$, and it was $800 \mathrm{rpm}$ during the cool down period. The temperature was measured by an IR sensor (Anton Paar Monowave 400, Graz, Austria). The pressure inside the glass vessel was also monitored throughout the experiments, through the septum that covers it. The experimental conditions were set based on previous experiments not included.

\subsection{Methodology Based on the Design of Experiments}

A two-level factorial design with three central points was carried out. The $\mathrm{FeCl}_{3}$ concentration in the range of 0.1 and $0.3 \mathrm{M}$, the process time from 1 to $5 \mathrm{~min}$, and the temperature between 170 and $200{ }^{\circ} \mathrm{C}$ were selected as factors, with a total of 11 experiments (Table 1 ).

The samples obtained in the microwave reactor were analyzed in high performance liquid chromatography (HPLC), as detailed in Section 4.4, and the results in terms of xylose conversion, furfural yield, and selectivity, as defined below, were taken as responses and statistically analyzed with the commercial software Design Expert 7.0.0, Stat-Ease Inc (Minneapolis, MN, USA).

On the basis of the data obtained from this first factorial design, a second rotatable composite central design was performed, where the range of variation for the factors was reduced as follows: the concentration of $\mathrm{FeCl}_{3}, 0.05-0.1 \mathrm{M}$; time, 0.5-1 min; and temperature, $190-200{ }^{\circ} \mathrm{C}$. Moreover, five center and star points (values above and below the experimental range for each of the factors) were added (Table 3).

The liquors obtained were measured in HPLC and analyzed statistically as in the previous design. These results were optimized to obtain the maximum yield of furfural and selectivity.

\subsection{Analysis of the Liquid Fractions and Quantification of the Yield, Selectivity, and Conversion}

The liquors obtained in the microwave reactor were analyzed by high performance liquid chromatography (HPLC). The compounds were determined using an Agilent Technologies 1260 model (Santa Clara, CA, USA) with ICSep ICE-COREGEL 87H3 column operating at $65{ }^{\circ} \mathrm{C}$ with $5 \mathrm{mM}$ sulfuric acid as the mobile phase $(0.6 \mathrm{~mL} / \mathrm{min})$. Samples were previously filtered through $0.45 \mu \mathrm{m}$ nylon membranes.

Conversion of xylose, furfural selectivity, and yield were defined as follows:

$$
\begin{gathered}
\text { Xylose conversion }(\%)=\frac{\text { Consumed xylose }}{\text { Initial xylose }} \times 100 \\
\text { Furfural yield }(\%)=\frac{\text { Furfural produced }}{\text { Furfural stoichiometric potential }(*)} \times 100
\end{gathered}
$$


$\left.{ }^{*}\right)$ Furfural stoichiometric potential $=$ Initial $x y l o s e \times 0.64$

$$
\text { Xylose conversion }(\%)=\frac{\text { Consumed xylose }}{\text { Initial xylose }} \times 100
$$

\section{Conclusions}

The analysis and comparison of results demonstrated the following:

Furfural can be obtained by dehydration of xylose, the main pentose found in lignocellulosic materials, thus making use of these renewable sources of energy and biobased chemicals. Temperature, time, and the concentration of iron chloride were identified as relevant factors of the conversion process. Following a two experimental design approach and optimization by response surface methodology, a highest yield of $57.1 \%$ along with $98.5 \%$ conversion was obtained. The experimental conditions leading to the best result, including the highest temperature assayed $\left(210^{\circ} \mathrm{C}\right)$ and lowest iron chloride concentration $(0.05 \mathrm{M})$ and process time $(0.5 \mathrm{~min})$, can be used as a starting point for the study of the conversion process using the whole lignocellulosic material, after being subjected to the required operations.

The processes used to obtain xylose-rich liquors from lignocellulosic materials should be selective on the hemicelluloses to solubilize the minimum amount of lignin, as this negatively affects the production of furfural.

The use of microwave heating in both monophase and biphase systems allows shorter reaction times, around one-third compared with conventional heating methods, which saves time and probably also energy.

The highest furfural yield values are obtained at high temperatures and at short times in both monophase and biphase systems.

Biphase systems increase the furfural yield on average by about $30 \%$ compared with monophase systems, in each case, using green solvents.

Future investigations will be focused on the use of microwaves for heating and a biphase system with green solvents on a xylose-rich liquor obtained from lignocellulosic materials. The methodology found here to obtain the optimal conditions of temperature, time, and concentration of catalyst will be applied to obtain furfural with a high yield. According to the current results, we would propose that high temperatures, above $200{ }^{\circ} \mathrm{C}$, should be tested.

Author Contributions: Conceptualization, E.R. and E.C.; methodology, C.P.-R.; software, J.M.R.-G.; validation, E.R. and E.C.; formal analysis, E.R.; investigation, C.P.-R.; resources, E.R. and E.C.; data curation, C.P.-R. and J.M.R.-G.; writing-original draft preparation, C.P.-R. and J.M.R.-G.; writing-review and editing, E.C.; visualization, C.P.-R. and J.M.R.-G.; supervision, E.R.; project administration, E.R.; funding acquisition, E.R. and E.C. All authors have read and agreed to the published version of the manuscript.

Funding: The authors want to acknowledge the financial support from Agencia Estatal de Investigación (MICINN, Spain) and Fondo Europeo de Desarrollo Regional, reference project ENE2017-85819-C2-1-R.

Acknowledgments: C.P.-R. was supported by Universidad de Jaén (research grant R5/04/2017).

Conflicts of Interest: The authors declare no conflict of interest.

\section{References}

1. Machado, G.; Leon, S.; Santos, F.; Lourega, R.; Dullius, J.; Mollmann, M.E.; Eichler, P. Literature Review on Furfural Production from Lignocellulosic Biomass. Nat. Resour. 2016, 07, 115-129. [CrossRef]

2. Cai, C.M.; Zhang, T.; Kumar, R.; Wyman, C.E. Integrated furfural production as a renewable fuel and chemical platform from lignocellulosic biomass: Furfural production from lignocellulosic biomass. J. Chem. Technol. Biotechnol. 2014, 89, 2-10. [CrossRef]

3. Dias, A.S.; Lima, S.; Pillinger, M.; Valente, A.A. Acidic cesium salts of 12-tungstophosphoric acid as catalysts for the dehydration of xylose into furfural. Carbohydr. Res. 2006, 341, 2946-2953. [CrossRef] [PubMed]

4. Rong, C.; Ding, X.; Zhu, Y.; Li, Y.; Wang, L.; Qu, Y.; Ma, X.; Wang, Z. Production of furfural from xylose at atmospheric pressure by dilute sulfuric acid and inorganic salts. Carbohydr. Res. 2012, 350, 77-80. [CrossRef] 
5. Sánchez, C.; Serrano, L.; Andres, M.A.; Labidi, J. Furfural production from corn cobs autohydrolysis liquors by microwave technology. Ind. Crops Prod. 2013, 42, 513-519. [CrossRef]

6. Montané, D.; Salvadó, J.; Torras, C.; Farriol, X. High-temperature dilute-acid hydrolysis of olive stones for furfural production. Biomass Bioenerg. 2002, 22, 295-304. [CrossRef]

7. Mesa, L.; Morales, M.; González, E.; Cara, C.; Romero, I.; Castro, E.; Mussatto, S.I. Restructuring the processes for furfural and xylose production from sugarcane bagasse in a biorefinery concept for ethanol production. Chem. Eng. Process. 2014, 85, 196-202. [CrossRef]

8. Sádaba, I.; Ojeda, M.; Mariscal, R.; Granados, M.L. Silica-poly(styrenesulphonic acid) nanocomposites for the catalytic dehydration of xylose to furfural. Appl. Catal. B Environ. 2014, 150-151, 421-431. [CrossRef]

9. Agirrezabal-Telleria, I.; Gandarias, I.; Arias, P.L. Heterogeneous acid-catalysts for the production of furan-derived compounds (furfural and hydroxymethylfurfural) from renewable carbohydrates: A review. Catal. Today 2014, 234, 42-58. [CrossRef]

10. Le Guenic, S.; Delbecq, F.; Ceballos, C.; Len, C. Microwave-assisted dehydration of D-xylose into furfural by diluted inexpensive inorganic salts solution in a biphasic system. J. Mol. Catal. A Chem. 2015, 410, 1-7. [CrossRef]

11. Padilla-Rascón, C.; Ruiz, E.; Romero, I.; Castro, E.; Oliva, J.M.; Ballesteros, I.; Manzanares, P. Valorisation of olive stone by-product for sugar production using a sequential acid/steam explosion pretreatment. Ind. Crops Prod. 2020, 148, 112279. [CrossRef]

12. Kim, S.B.; Lee, J.H.; Yang, X.; Lee, J.; Kim, S.W. Furfural production from hydrolysate of barley straw after dilute sulfuric acid pretreatment. Korean J. Chem. Eng. 2015, 32, 2280-2284. [CrossRef]

13. Zhang, L.; Yu, H.; Wang, P.; Li, Y. Production of furfural from xylose, xylan and corncob in gamma-valerolactone using $\mathrm{FeCl}_{3} \cdot 6 \mathrm{H}_{2} \mathrm{O}$ as catalyst. Bioresour. Technol. 2014, 151, 355-360. [CrossRef] [PubMed]

14. Marcotullio, G.; De Jong, W. Chloride ions enhance furfural formation from d-xylose in dilute aqueous acidic solutions. Green Chem. 2010, 12, 1739. [CrossRef]

15. Nie, Y.; Hou, Q.; Li, W.; Bai, C.; Bai, X.; Ju, M. Efficient Synthesis of Furfural from Biomass Using $\mathrm{SnCl}_{4}$ as Catalyst in Ionic Liquid. Molecules 2019, 24, 594. [CrossRef] [PubMed]

16. Romero, I.; Ruiz, E.; Castro, E. Pretreatment with Metal Salts. In Biomass Fractionation Technologies for a Lignocellulosic Feedstock Based Biorefinery; Elsevier: Amsterdam, The Netherlands, 2016; pp. 209-227. ISBN 978-0-12-802323-5.

17. Weingarten, R.; Cho, J.; Conner, W.C., Jr.; Huber, G.W. Kinetics of furfural production by dehydration of xylose in a biphasic reactor with microwave heating. Green Chem. 2010, 12, 1423. [CrossRef]

18. Hricovíniová, Z. Xylans are a valuable alternative resource: Production of d-xylose, d-lyxose and furfural under microwave irradiation. Carbohydr. Polym. 2013, 98, 1416-1421. [CrossRef]

19. Yemiş, O.; Mazza, G. Acid-catalyzed conversion of xylose, xylan and straw into furfural by microwave-assisted reaction. Bioresour. Technol. 2011, 102, 7371-7378. [CrossRef]

20. Zhang, Y.; Wang, Z.; Feng, J.; Pan, H. Maximizing utilization of poplar wood by microwave-assisted pretreatment with methanol/dioxane binary solvent. Bioresour. Technol. 2020, 300, 122657. [CrossRef]

21. Mikulski, D.; Kłosowski, G. Microwave-assisted dilute acid pretreatment in bioethanol production from wheat and rye stillages. Biomass Bioenerg. 2020, 136, 105528. [CrossRef]

22. Benko, Z.; Andersson, A.; Gáspár, M.; Réczey, K.; Stålbrand, H. Heat extraction of corn fiber hemicellulose. Appl. Biochem. Biotechnol. 2007, 136, 14.

23. Mashuni; Hamid, F.H.; Muzuni; Kadidae, L.O.; Jahiding, M.; Ahmad, L.O.; Saputra, D. The determination of total phenolic content of cocoa pod husk based on microwave-assisted extraction method. AIP Conf. Proc. 2020, 2243, 030013. [CrossRef]

24. Ji, Q.; Yu, X.; Yagoub, A.E.-G.A.; Chen, L.; Zhou, C. Efficient removal of lignin from vegetable wastes by ultrasonic and microwave-assisted treatment with ternary deep eutectic solvent. Ind. Crops Prod. 2020, 149, 112357. [CrossRef]

25. Riansa-ngawong, W.; Prasertsan, P. Optimization of furfural production from hemicellulose extracted from delignified palm pressed fiber using a two-stage process. Carbohydr. Res. 2011, 346, 103-110. [CrossRef] [PubMed]

26. Yang, W.; Li, P.; Bo, D.; Chang, H. The optimization of formic acid hydrolysis of xylose in furfural production. Carbohydr. Res. 2012, 357, 53-61. [CrossRef] 
27. Yang, W.; Li, P.; Bo, D.; Chang, H.; Wang, X.; Zhu, T. Optimization of furfural production from d-xylose with formic acid as catalyst in a reactive extraction system. Bioresour. Technol. 2013, 133, 361-369. [CrossRef]

28. Lamminpää, K.; Tanskanen, J. Study of furfural formation using formic acid. In Proceedings of the 8th World Congress of Chemical Engineering, Montréal, QC, Canada, 23 August 2009.

29. Lamminpää, K.; Ahola, J.; Tanskanen, J. Acid-catalysed xylose dehydration into furfural in the presence of kraft lignin. Bioresour. Technol. 2015, 177, 94-101. [CrossRef]

30. Rasmussen, H.; Sørensen, H.R.; Meyer, A.S. Formation of degradation compounds from lignocellulosic biomass in the biorefinery: Sugar reaction mechanisms. Carbohydr. Res. 2014, 385, 45-57. [CrossRef]

31. Peleteiro, S.; Rivas, S.; Alonso, J.L.; Santos, V.; Parajó, J.C. Furfural production using ionic liquids: A review. Bioresour. Technol. 2016, 202, 181-191. [CrossRef]

32. Jeong, G.H.; Kim, E.G.; Kim, S.B.; Park, E.D.; Kim, S.W. Fabrication of sulfonic acid modified mesoporous silica shells and their catalytic performance with dehydration reaction of d-xylose into furfural. Micropor. Mesopor. Mat. 2011, 144, 134-139. [CrossRef]

33. O'Neill, R.; Ahmad, M.N.; Vanoye, L.; Aiouache, F. Kinetics of Aqueous Phase Dehydration of Xylose into Furfural Catalyzed by ZSM-5 Zeolite. Ind. Eng. Chem. Res. 2009, 48, 4300-4306. [CrossRef]

34. Xiouras, C.; Radacsi, N.; Sturm, G.; Stefanidis, G.D. Furfural Synthesis from D -Xylose in the Presence of Sodium Chloride: Microwave versus Conventional Heating. Chem. Sus. Chem. 2016, 9, 2159-2166. [CrossRef] [PubMed]

35. Kim, E.S.; Liu, S.; Abu-Omar, M.M.; Mosier, N.S. Selective Conversion of Biomass Hemicellulose to Furfural Using Maleic Acid with Microwave Heating. Energ. Fuel 2012, 26, 1298-1304. [CrossRef]

36. Möller, M.; Schröder, U. Hydrothermal production of furfural from xylose and xylan as model compounds for hemicelluloses. RSC Adv. 2013, 3, 22253. [CrossRef]

37. Antal, M.J.; Leesomboon, T.; Mok, W.S.; Richards, G.N. Mechanism of formation of 2-furaldehyde from d-xylose. Carbohydr. Res. 1991, 217, 71-85. [CrossRef]

38. Hongsiri, W.; Danon, B.; Jong, W. de Kinetic Study on the Dilute Acidic Dehydration of Pentoses toward Furfural in Seawater. Ind. Eng. Chem. Res. 2014, 53, 5455-5463. [CrossRef]

39. Mellmer, M.A.; Sener, C.; Gallo, J.M.R.; Luterbacher, J.S.; Alonso, D.M.; Dumesic, J.A. Solvent Effects in Acid-Catalyzed Biomass Conversion Reactions. Angew. Chem. Int. Ed. 2014, 53, 11872-11875. [CrossRef]

40. Gallo, J.M.R.; Alonso, D.M.; Mellmer, M.A.; Yeap, J.H.; Wong, H.C.; Dumesic, J.A. Production of Furfural from Lignocellulosic Biomass Using Beta Zeolite and Biomass-Derived Solvent. Top. Catal. 2013, 56, 1775-1781. [CrossRef]

41. Gürbüz, E.I.; Gallo, J.M.R.; Alonso, D.M.; Wettstein, S.G.; Lim, W.Y.; Dumesic, J.A. Conversion of Hemicellulose into Furfural Using Solid Acid Catalysts in $\gamma$-Valerolactone. Angew. Chem. Int. Ed. 2013, 52, 1270-1274. [CrossRef]

42. Kim, S.B.; You, S.J.; Kim, Y.T.; Lee, S.; Lee, H.; Park, K.; Park, E.D. Dehydration of D-xylose into furfural over H-zeolites. Korean J. Chem. Eng. 2011, 28, 710-716. [CrossRef]

43. Dias, A.S.; Pillinger, M.; Valente, A.A. Liquid phase dehydration of d-xylose in the presence of Keggin-type heteropolyacids. Appl. Catal. A Gen. 2005, 285, 126-131. [CrossRef]

44. Lam, E.; Majid, E.; Leung, A.C.W.; Chong, J.H.; Mahmoud, K.A.; Luong, J.H.T. Synthesis of Furfural from Xylose by Heterogeneous and Reusable Nafion Catalysts. Chem. Sus. Chem. 2011, 4, 535-541. [CrossRef] [PubMed]

45. Choudhary, V.; Pinar, A.B.; Sandler, S.I.; Vlachos, D.G.; Lobo, R.F. Xylose Isomerization to Xylulose and its Dehydration to Furfural in Aqueous Media. ACS Catal. 2011, 1, 1724-1728. [CrossRef]

46. Binder, J.B.; Blank, J.J.; Cefali, A.V.; Raines, R.T. Synthesis of Furfural from Xylose and Xylan. Chem. Sus. Chem. 2010, 3, 1268-1272. [CrossRef] [PubMed]

47. Lima, S.; Neves, P.; Antunes, M.M.; Pillinger, M.; Ignatyev, N.; Valente, A.A. Conversion of mono/di/polysaccharides into furan compounds using 1-alkyl-3-methylimidazolium ionic liquids. Appl. Catal. A Gen. 2009, 363, 93-99. [CrossRef]

48. Zhang, Z.; Du, B.; Quan, Z.-J.; Da, Y.-X.; Wang, X.-C. Dehydration of biomass to furfural catalyzed by reusable polymer bound sulfonic acid (PEG-OSO3H) in ionic liquid. Catal. Sci. Technol. 2014, 4, 633. [CrossRef]

49. Le Guenic, S.; Gergela, D.; Ceballos, C.; Delbecq, F.; Len, C. Furfural Production from d-Xylose and Xylan by Using Stable Nafion NR50 and NaCl in a Microwave-Assisted Biphasic Reaction. Molecules 2016, 21, 1102. [CrossRef] 
50. Peleteiro, S.; da Costa Lopes, A.M.; Garrote, G.; Parajó, J.C.; Bogel-Łukasik, R. Simple and Efficient Furfural Production from Xylose in Media Containing 1-Butyl-3-Methylimidazolium Hydrogen Sulfate. Ind. Eng. Chem. Res. 2015, 54, 8368-8373. [CrossRef]

51. vom Stein, T.; Grande, P.M.; Leitner, W.; Domínguez de María, P. Iron-Catalyzed Furfural Production in Biobased Biphasic Systems: From Pure Sugars to Direct Use of Crude Xylose Effluents as Feedstock. Chem. Sus. Chem. 2011, 4, 1592-1594. [CrossRef]

52. Campos Molina, M.J.; Mariscal, R.; Ojeda, M.; López Granados, M. Cyclopentyl methyl ether: A green co-solvent for the selective dehydration of lignocellulosic pentoses to furfural. Bioresour. Technol. 2012, 126, 321-327. [CrossRef]

53. Wang, W.; Li, H.; Ren, J.; Sun, R.; Zheng, J.; Sun, G.; Liu, S. An efficient process for dehydration of xylose to furfural catalyzed by inorganic salts in water/dimethyl sulfoxide system. Chinese J. Catal. 2014, 35, 741-747. [CrossRef]

54. Li, H.; Ren, J.; Zhong, L.; Sun, R.; Liang, L. Production of furfural from xylose, water-insoluble hemicelluloses and water-soluble fraction of corncob via a tin-loaded montmorillonite solid acid catalyst. Bioresour. Technol. 2015, 176, 242-248. [CrossRef] [PubMed]

55. Tao, F.; Song, H.; Chou, L. Efficient process for the conversion of xylose to furfural with acidic ionic liquid. Can. J. Chem. 2011, 89, 83-87. [CrossRef]

56. Serrano-Ruiz, J.C.; Campelo, J.M.; Francavilla, M.; Romero, A.A.; Luque, R.; Menéndez-Vázquez, C.; García, A.B.; García-Suárez, E.J. Efficient microwave-assisted production of furfural from C5 sugars in aqueous media catalysed by Brönsted acidic ionic liquids. Catal. Sci. Technol. 2012, 2, 1828. [CrossRef]

57. Yang, Y.; Hu, C.-W.; Abu-Omar, M.M. Synthesis of Furfural from Xylose, Xylan, and Biomass Using $\mathrm{AlCl} 3.6 \mathrm{H} 2 \mathrm{O}$ in Biphasic Media via Xylose Isomerization to Xylulose. Chem. Sus. Chem. 2012, 5, 405-410. [CrossRef] [PubMed]

Sample Availability: Samples of the compounds are not available from the authors.

(C) 2020 by the authors. Licensee MDPI, Basel, Switzerland. This article is an open access article distributed under the terms and conditions of the Creative Commons Attribution (CC BY) license (http://creativecommons.org/licenses/by/4.0/). 